\title{
Effect of a health-risk reduction training program on the knowledge and safe waste-handling practices among Waste-pickers in dumpsites in Ogun State, Nigeria
} Ayodeji T1므, Amosu AM $\underline{21} \underline{\mathrm{D}}$

${ }^{1}$ Department of Public Health, Babcock University, Ilishan Remo-Ogun State ${ }^{2}$ Department of Public Health, Babcock University, Ilishan Remo Ogun State

Submitted: $21^{\text {st }}$ September 2021

Accepted: $18^{\text {th }}$ November 2021

Published: $30^{\text {th }}$ December 2021

ID: Orcid ID

\begin{abstract}
Objective: This study assessed the effect of a health-risk reduction training program on waste-pickers wastehandling practices in dumpsites in Ogun State, Nigeria.

Methods: A quasi-experimental study was conducted among 60 waste-pickers recruited by multistage sampling technique divided into intervention and control group. There was a baseline assessment of waste-handling practices in both intervention and control groups using a structured interviewer-administered questionnaire. Thereafter, health-risk reduction training was given using lectures, and demonstrations. Three months after the intervention, another assessment of the same waste-pickers was conducted with the same instrument. Wastehandling practices and knowledge responses were measured on a 54-point rating scale and 17-point rating scale respectively. Data were analyzed using IBM SPSS version 23 to generate descriptive and inferential.

Results: At baseline, the waste-pickers in the control group had a mean waste-handling score of $17.80 \pm 6.89$ while the experimental group had a mean of $(17.97 \pm 5.47)$. After the training program, there was a statistically significant increase in the mean waste-handling score of the experimental group $(47.30 \pm 3.28 ; p=0.000)$ while there was no increase in the mean waste-handling score of the control group (17.80 \pm 6.89$)$. This significant increase in the mean waste-handling score of the experimental group $(53.83 \pm 0.38 ; p=0.000)$ was also observed at 3 month follow-up period.

Conclusion/Recommendation: The health-risk reduction training was effective in improving the waste-handling practices of waste-pickers. It is recommended that waste-pickers should be trained on proper waste-handling by the government.
\end{abstract}

Keywords: Dumpsite, Health-risk reduction, Knowledge, Waste-pickers, Waste-handling

\section{Plain English Summary}

Waste-pickers working in open dumpsites face the most direct risk of exposure to solid waste affecting their health. Hence, this study assessed the effect of a health-risk reduction training program on waste-pickers waste-handling practices in dumpsites in Ogun State, Nigeria. The quasi-experimental design was adopted involving a sample of 60 waste-pickers selected from two dumpsites in Ogun State assigned into the control and intervention groups. Before the training program, there was no statistically significant difference in the waste-picker mean waste-handling score in the control group and the intervention group $(p>0.05)$ After the training program there was a statistically significant increase in the mean waste-handling score of the experimental group $(47.30 \pm 3.28 ; p=0.000)$ while there was no increase in the mean waste-handling score

\section{Correspondence:}

Tella, Ayodeji

Department of Public Health,

Babcock University, Ilishan

+2348023070756, ayotella1955@gmail.com

(c) BUMJ. 2020 Open Access This article is distributed under the terms of the Creative Commons Attribution 4.0 International License (http://creativecommons.org/licenses/by/4.0/), which permits unrestricted use, distribution, and reproduction in any medium, provided you give appropriate credit to the original author(s) and the source, provide a link to the Creative Commons license, and indicate if changes were made. The Creative Commons Public Domain Dedication waiver (http://creativecommons.org/publicdomain/zero/1.0/) applies to the data made available in this article, unless otherwise stated. 
of the control group (17.80 \pm 6.89$)$. This significant increase in the mean waste-handling score of the experimental group $(53.83 \pm 0.38 ; p=0.000)$ was also observed during the third-month follow-up period. The results of that study showed that health-risk reduction training was effective in improving the waste-handling practices of waste-pickers.

\section{Background}

Nigeria with an estimated 200 million people accounts for $20 \%$ of the total population in subSaharan African (1). Municipal solid waste generation has been increasing due to waste generated daily by individuals in the country (2). This rapid population growth and industry has led to an increase in the use of materials capable of producing hazardous wastes. Waste is always generated when human beings engage in economic activities and various materials are used. Such waste can be hazardous or nonhazardous. When waste is not handled properly, it can pose a risk to the atmosphere, the water, soil, and living organisms (3). The waste generation rate in Nigeria is estimated at 0.65$0.95 \mathrm{~kg} /$ capita/day which gives an average of 42 million tonnes of wastes generated annually. This is more than half of 62 million tonnes of waste generated in sub-Sahara Africa annually and how and where to dispose of this waste becomes a huge problem for the nation; only about $20-30 \%$ of the waste is gathered and $70 \%$ are dumped in treacherous places $(2,4)$. It is common to find large heaps of garbage lying in a disorganized manner in and around cities as a result of the failure of municipal corporations to handle large quantities of waste (4).

Disposal of solid waste at a landfill site is the primary disposal method used in most developing countries including Nigeria (5). Most of the wastes dumped are decomposable materials while the remaining recyclables are picked up by waste pickers or scavengers (6). Waste-pickers were described as those who make a living by collecting and selling recyclable materials out of municipal solid waste (7). Scavenging is a widespread and regular activity in nearly all cities in developing countries. Some waste pickers work at a single site that holds a great quantity of waste like dumpsites, or transfer stations. While some are dynamic, collecting materials from factories, offices, stores, schools, hospitals, and residential areas. Others work at dumpsites, canals, and rivers where people dump their refuse (8). It is projected globally, that about two million persons work informally as waste pickers. These groups of persons are the first to suffer the consequences of the poor management of solid wastes (9). They engage in waste separation, waste reuse, aiding recycling, and reducing pressure on the environment. They often do not wear any protective equipment and face great risks of injuries linked to the type of material they are collecting (10). These waste pickers are vulnerable to injuries owing to a lack of the needed personal protective equipment (PPE) and consequently are faced with deplorable working conditions. Scavenging is therefore considered a treacherous occupation (11). Researchers have proposed that protective equipment which includes proper clothing, gloves, and boots should be made available to scavengers, to reduce pathogenic infections and improve their activities $(12,13,14)$. Hence this study determines the effect of health-risk reduction training programs on knowledge and safe wastehandling practices among waste-pickers in dumpsites in Ogun State, Nigeria.

\section{Methods}

The present study was carried out at the OkeSaje dumpsite and lkoto dumpsite in Ogun State. A quasi-experimental study design was applied to assess the effect of health-risk reduction training on waste-pickers knowledge and waste-handling practices.

For the intervention program, 60 waste-pickers were selected; $50 \%$ of waste pickers (30) were subjected to the pre-developed educational health-risk training program (Intervention group) while the other $50 \%$ (30) was not and was designated as (Control group). Both groups were subjected to a pre-test and two post-tests, one immediately after the end of the intervention program, and the other, three months later. A predesigned and pre-coded intervieweradministered questionnaire was filled by the waste-pickers, to assess their waste-handling practices.

The knowledge question on solid waste-handling consists of seventeen questions. This evaluates the waste pickers' knowledge of solid waste handling/exposure, and the health effects of waste. It comprises multiple-choice and dichotomous of Yes/ No. The knowledge questions were scored as follows: score "1" for a correct answer, Score "0" for an incorrect answer, and for don't know. The total mean knowledge score was calculated for each question by summing up every category, and total scores were calculated $(17 \times 1=17)$ ranging from $(0-17$ 
points), then were adjusted out of 100 (0\%-100\%) and were graded as follows: poor knowledge (08.5points) and good knowledge (8.6-17).

The safe waste-handling practice questions were scored as follows: Score "2" for 'every time' answer, Score 1 for sometimes answer, and Score 0 for never answer

The total mean safe waste-handling score was calculated for each question by summing up every category, and total scores were calculated $(27 \times 2=54)$ ranging from ( $0-54$ points); then were adjusted out of $100(0 \%-100 \%)$ and were graded as follows: Good level of waste-handling practice (28-54 points) $>50 \%$, Poor level of wastehandling practice $(0-27$ points $) \leq 50 \%$.

\section{Intervention program}

An intervention program was designed according to the results of the pre-test. The program was structured according to the needs of the wastepickers under study. The training manual was prepared, reviewed, and tested before use. The training program was facilitated by the researcher who is an environmental health consultant.

Four training modules were delivered over four weeks; the participants' attended the sessions in the morning from 10:00 am to 11:30 am, once weekly. The methods used in the intervention program included: lectures and demonstrations. The contents of the four sessions of the health training intervention program were as follows: Environmental effect of solid waste, the importance of preventing exposure to solid waste from entering the body, diagnosis, first-aid, and treatment of disease-related to waste handling and disposal. There is also a practical demonstration of the use of PPE and personal hygiene.
Statistical analysis

Data were collected, revised, coded with their input to the statistical software IBM SPSS (Statistical Package for the Service Solution) version 23. Descriptive statistics including frequency distribution and percentages were performed. For quantitative variables, mean and standard deviation were calculated. Inferential statistics include $t$-test and Cohen d effect size. The two-tailed tests, alpha error of 0.05 , and $p$ value less than 0.05 were considered significant.

\section{Results \\ Socio-demographic Characteristics of the Waste- Pickers}

The mean ages of the waste-pickers in the intervention and the control groups were $25.27 \pm 4.90$ and $29.90 \pm 4.44$ respectively. Their ages ranged from 18 to 43years. Most of the participants in the two groups were within the 2429 age brackets. All the participants in the two groups were male. Half of the participants in the intervention were married while $60 \%$ in the control group were married. Most of the participants in the two groups were of the Islamic faith. While only $16.7 \%$ and $33.3 \%$ of the participants were Christians in the experimental and the control group respectively. Fifty percent of the participants in the experimental group had no formal education with only $6.7 \%$ of the participants with tertiary education, while $20 \%$ of the participants in the control group had no formal education with only $3.3 \%$ of the participants with tertiary education. Most of the participants in the two groups lived in temporary shelters in the dumpsite. Most of the participants in the two groups had been scavenging for between 5-6 years (See, Table 1).

Table 1: Socio-demographic characteristics of waste-pickers in the Experimental and Control Group

\begin{tabular}{|c|c|c|c|c|}
\hline Variables & $\begin{array}{c}\text { Experimental } \\
F(\%)\end{array}$ & $\begin{array}{c}\text { Control N } \\
\mathrm{F}(\%)\end{array}$ & Statistics & $p$-value \\
\hline Age(years) & $25.27 \pm 4.90$ & $29.90 \pm 4.44$ & $F=14.746$ & 0.000 \\
\hline $18-23$ & $13(43.3)$ & $1(3.3)$ & & \\
\hline $24-29$ & 13 (43.3) & $15(50.0)$ & & \\
\hline $30-35$ & $2(6.7)$ & $12(40.0)$ & & \\
\hline $36-41$ & $2(6.7)$ & $0(0.0)$ & & \\
\hline $42-47$ & $0(0.0)$ & $2(6.7)$ & & \\
\hline \multicolumn{5}{|l|}{ Gender } \\
\hline Male & $30(100)$ & $30(100)$ & & \\
\hline Religion & & & $F=2.231$ & 0.141 \\
\hline Christian & $5(16.7)$ & $10(33.3)$ & & \\
\hline Islam & 25 (83.3) & $20(66.7)$ & & \\
\hline Marital Status & & & $F=0.592$ & 0.445 \\
\hline
\end{tabular}




\begin{tabular}{|c|c|c|c|c|}
\hline Married & $15(50.0)$ & $18(60.0)$ & \multirow{4}{*}{$F=2.328$} & \multirow[b]{3}{*}{0.132} \\
\hline Single & $15(50.0)$ & $12(40.0)$ & & \\
\hline Educational Status & & & & \\
\hline Non-Formal & $15(50.0)$ & $6(20.0)$ & & \multirow[b]{5}{*}{0.045} \\
\hline Primary School & $12(40.0)$ & $20(66.7)$ & \multirow{5}{*}{$F=4.193$} & \\
\hline Secondary School & $1(3.3)$ & $3(10.0)$ & & \\
\hline University Education & $2(6.7)$ & $1(3.3)$ & & \\
\hline Where do you live & & & & \\
\hline Rented Apartment & $2(6.7)$ & $3(10.0)$ & & \\
\hline Relative/Friends & $1(3.3)$ & $1(3.3)$ & \multirow{7}{*}{$F=1.627$} & \multirow{7}{*}{0.207} \\
\hline Own Home/ Family & $0(0.0)$ & $1(3.3)$ & & \\
\hline Temporary shelter in dump site & $27(90.0)$ & $25(83.3)$ & & \\
\hline How long have you been scavenging? & & & & \\
\hline $1-5$ & $7(23.3)$ & $6(20.0)$ & & \\
\hline $6-10$ & $19(63.3)$ & $17(56.7)$ & & \\
\hline $11-15$ & $4(13.3)$ & $7(23.3)$ & & \\
\hline
\end{tabular}

Baseline Knowledge and Safe Waste-handling Practices of Waste-pickers

The mean \pm SD scores for the waste-pickers level of knowledge on waste handling practices in the experimental and control groups were $7.17 \pm 1.64$ and $6.53 \pm 2.43$. Only $30 \%$ in the experimental group, had good knowledge of waste handling practices while a much lower proportion $16.7 \%$ in the control group, had good knowledge. When the waste-pickers mean scores of levels of knowledge on waste handling practices measured in this study were compared for the control and experimental groups at baseline, independent t-test computation showed that there was no significant difference $(P>0.05)$ (See, Table 2).

Furthermore, the waste-pickers mean score and standard deviation for the control and the experimental groups were $17.97 \pm 5.47$ and 17.80 \pm 6.89 . All of the participants in the intervention group had a low practice of waste handling while $93.3 \%$ of the control group had low practice. When waste-pickers waste handling mean scores measured in this study were compared for the control and the intervention group at baseline, independent t-test computations showed no significant difference $(P>0.05)$ (See, Table 2).

Table 2: Baseline knowledge and Safe Waste-handling Practices of Waste-pickers

\begin{tabular}{|c|c|c|c|c|}
\hline Knowledge of Waste Handling Practices & $\begin{array}{c}\text { Experimental } \\
\mathrm{F}(\%) \\
\end{array}$ & $\begin{array}{c}\text { Control F } \\
(\%)\end{array}$ & $\begin{array}{c}\text { Statistics } \\
\mathrm{t}=\text { value }\end{array}$ & $p$-value \\
\hline \multicolumn{5}{|c|}{ Measured on a 17-point Rating Scale } \\
\hline Poor (0-8.5) & $21(70.0)$ & $25(83.3)$ & & \\
\hline Good (8.6-17) & $9(30.0)$ & $5(16.7)$ & & \\
\hline Mean \pm SD & $7.17 \pm 1.64$ & $6.53 \pm 2.43$ & 1.18 & 0.24 \\
\hline \multicolumn{5}{|c|}{ Measured on a 54-point Rating Scale } \\
\hline Poor & $30(100.0)$ & $28(93.3)$ & & \\
\hline $\begin{array}{l}\text { Good } \\
\text { Mean } \pm \text { SD }\end{array}$ & $\begin{array}{c}0(0.0) \\
17.97 \pm 5.47\end{array}$ & $\begin{array}{c}2(6.7) \\
17.80 \pm 6.89\end{array}$ & 0.104 & 0.918 \\
\hline
\end{tabular}

The effect of the Training Program on Wastepicker Knowledge and Safe Waste-handling Practices

The effects of the training program are summarized in table three. Overall, the intervention group showed significantly higher mean knowledge scores than the control group at immediate post-intervention and follow-up period $(P<0.05)$. The intervention group and control group had a mean knowledge score of $11.93 \pm 1.64$ and $7.17 \pm 1.64$ respectively at immediate post-intervention. At the follow-up period, the intervention group had a mean knowledge score of $14.37 \pm 2.86$ while there was no increase in the mean knowledge score of the control group $(7.17 \pm 1.64)$.

Furthermore, the waste-pickers safe wastehandling practices mean score for the 
experimental group increases significantly at immediate post-intervention $(47.30 \pm 3.28)$ compared with the control group mean score $(17.80 \pm 6.89)(p<0.05)$. Also, there was a significant increase in waste-handling practices of the intervention group compared with the control group at the follow-up period $(p<0.05)$.

Table 3: The Effects of the Training Program on Waste-picker Knowledge and Safe waste-handling practices

\begin{tabular}{|c|c|c|c|c|c|c|}
\hline \multirow[t]{2}{*}{ Knowledge } & \multicolumn{3}{|c|}{ Experimental Group } & \multicolumn{3}{|c|}{ Control Group } \\
\hline & $\begin{array}{c}\text { Post } \\
\text { intervention }\end{array}$ & Follow-up & $p$-value & $\begin{array}{c}\text { Post } \\
\text { intervention }\end{array}$ & Follow-up & $\mathrm{p}$-value \\
\hline $\begin{array}{l}\text { Poor } \\
\text { Good } \\
\text { Mean } \pm \text { SD } \\
\text { Waste-handling practices }\end{array}$ & $\begin{array}{c}0(0.0) \\
30(100) \\
11.93 \pm 1.64\end{array}$ & $\begin{array}{c}0(0.0) \\
30(100) \\
14.37 \pm 2.86\end{array}$ & 0.001 & $\begin{array}{c}25(83.3) \\
5(16.7) \\
6.53 \pm 2.43\end{array}$ & $\begin{array}{c}25(83.3) \\
5(16.7) \\
6.53 \pm 2.43\end{array}$ & 0.62 \\
\hline $\begin{array}{l}\text { Poor } \\
\text { Good } \\
\text { Mean } \pm S D\end{array}$ & $\begin{array}{c}0(0.0) \\
30(100) \\
47.30 \pm 3.28\end{array}$ & $\begin{array}{c}0(0.0) \\
30(100) \\
53.83 \pm 0.38\end{array}$ & 0.001 & $\begin{array}{c}28(93.3) \\
2(6.7) \\
17.80 \pm 6.89\end{array}$ & $\begin{array}{c}28(93.3) \\
2(6.7) \\
17.80 \pm 6.89\end{array}$ & 0.49 \\
\hline
\end{tabular}

Comparison of the effect of the mean score of waste-pickers knowledge and Safe wastehandling practices between the baseline and the follow-up period

Evaluating the impact of the intervention on the waste-pickers level of knowledge on waste handling practices by comparing the baseline and the three months' follow-up means scores for the experimental group using paired sample t-test revealed that there was a statistically significant difference in the mean scores and the effect size computed indicating the magnitude of the differences in means between baseline and the 8th-week follow-up was significant. The intervention group had an effect size of -3.141 with a p-value of 0.000 . However, the control group had no effect size since there was no difference in the mean scores between the baseline and follow-up period (ES=0.000; $p=0.67$ ) (See Table 4).

In addition, evaluating the impact of the intervention on waste-pickers safe waste handling practices by comparing the baseline and the follow-up means scores for the experimental group using paired sample t-test, revealed that there were statistically significant differences in the mean scores and the effect size computed indicating the magnitude of the differences in means between baseline and the follow-up period was significant. The intervention group had an effect size of -9.407 with a p-value of 0.000 . However, the control group had no effect size since there was no difference in the mean score between the baseline and the follow-up period $(E S=0.000 ; p=0.49)($ See, Table 4).

Table 4: Comparison of the effect of the mean score of waste-pickers knowledge and wastehandling practices between the baseline and the follow-up period

\begin{tabular}{|c|c|c|c|c|c|c|c|c|}
\hline \multirow[t]{2}{*}{ Knowledge } & \multicolumn{4}{|c|}{ Experimental Group } & \multicolumn{4}{|c|}{ Control Group } \\
\hline & Baseline & Follow-up & p-value & ${ }^{*} \mathrm{ES}$ & Baseline & Follow-up & $p$-value & ${ }^{*} \mathrm{ES}$ \\
\hline $\begin{array}{l}\text { Poor } \\
\text { Good } \\
\text { Mean } \pm \text { SD } \\
\text { Waste-handling } \\
\text { practices }\end{array}$ & $\begin{array}{c}21(70.0) \\
9(30.0) \\
7.17 \pm 1.64\end{array}$ & $\begin{array}{c}0(0.0) \\
30(100) \\
14.37 \pm 2.86\end{array}$ & 0.001 & 3.14 & $\begin{array}{c}25(83.3) \\
5(16.7) \\
6.53 \pm 2.43\end{array}$ & $\begin{array}{c}25(83.3) \\
5(16.7) \\
6.53 \pm 2.43\end{array}$ & 0.67 & 0.000 \\
\hline $\begin{array}{l}\text { Poor } \\
\text { Good } \\
\text { Mean } \pm \text { SD }\end{array}$ & $\begin{array}{c}30(100.0) \\
0(0.0) \\
17.97 \pm 5.47\end{array}$ & $\begin{array}{c}0(0.0) \\
30(100) \\
53.83 \pm 0.38\end{array}$ & 0.001 & 9.40 & $\begin{array}{c}28(93.3) \\
2(6.7) \\
17.80 \pm 6.89\end{array}$ & $\begin{array}{c}28(93.3) \\
2(6.7) \\
17.80 \pm 6.89\end{array}$ & 0.49 & 0.000 \\
\hline
\end{tabular}

${ }^{*}$ ES: Effect size 


\section{Discussion}

This study evaluated the effect of a health-risk reduction intervention training program on wastepickers knowledge and waste-handling practices in dumpsites in Ogun State, Nigeria. The result of the analysis of the present study revealed that all the respondents in the intervention and the control group were male; this is similar to the findings by Magaji and Dakyes (15) who established in their research that the practice was mainly conducted by males in Abuja. However, the result is at variance with a study done at Onderstepoort dumpsite in South Africa where it was reported that both males and females engaged in the business of waste picking (16). This disparity in result could be a result of the difference in the study area. The overall mean age of respondents in the intervention and the control group was $27.58 \pm 5.2$ years with the age bracket of 24-29years. The study showed that more than half of the respondents in the intervention and control group had primary education. This finding conforms to those of Simatele and Etambakonga (17), where it was established that the highest level of education attained by their respondents was a primary school. Contrary to this study was a study in South Africa where the majority of the respondents attained secondary educational status in both groups (16). The result also showed that most of the respondents in both groups lived in a temporary shelter near the dumpsite.

Furthermore, this study shows that the baseline data on knowledge and waste-handling practices of the waste-pickers in the experimental group and the control group had no significant differences. This explains that the experimental and control group were matched before the intervention. This finding is similar to the finding of Thirarattanasunthon et al, (18). The present study revealed significant improvement in wastepickers knowledge regarding waste-handling after the intervention as compared with the control group. This indicates that the training program had a very good effect. This is due to the content of the training intervention program. The findings of the present study are supported by Thirarattanasunthon et al, (18) and Kumar, Somrongthong et al (19).

Concerning the waste-pickers waste-handling practices, this study revealed that there was a significant increase in the waste-pickers wastehandling practice after the training program, while the control remains the same. This finding is similar to the findings of Thirarattanasunthon et al, (19).
In conclusion, the health-risk reduction training led to a significant increase in the waste-pickers knowledge regarding waste-handling and also, improvement in their waste-handling practices. This implies that waste-pickers exposed to solid waste at dumpsites should be trained on how to properly use their protective equipment and adhere strictly to safety recommendations concerning routine work at these sites to help reduce health risks.

\section{Declarations}

Ethics approval and consent to participate

Written approvals from Babcock University Health Research Committee (BUHREC) and Ogun State Waste Management Authority (OGWAMA) were obtained, indicating that an academic research study within Oke-Saje and lkoto dumpsites was to be done. The sample participants agreeing to participate voluntarily in the study were informed of the date of the program. Confidentiality was ensured throughout the study period and only code numbers were used instead of the participants' names.

\section{Consent for publication}

The authors hereby give consent for the publication of our work under the creative commons CC Attribution-Non-commercial 4.0 license.

\section{Competing Interests}

There is no competing interest.

\section{Funding}

The research was funded by researchers.

\section{Authors' Contributions}

TA formulated the title, collected data, did the data analysis, and prepared the manuscript. AM reviewed the literature and collected the data.

\section{Acknowledgments}

We wish to acknowledge the waste-pickers that took part in the study for their immense support.

\section{References}

1. United Nations Population Report. World population 2019.2 prospects. https://population.un.org/wpp/Publications/Fil es/WPP2019 Highlights.pdf

2. Dlamini S, Simatele MD, Serge Kubanza N. Municipal solid waste management in South Africa: from waste to energy recovery through waste-to-energy technologies in Johannesburg. Local Environment. 2019 Mar 
4;24(3):249-57. https://doi.org/10.1080/13549839.2018.1561 $\underline{656}$

3. Ifeoluwa OB. Harmful effects and management of indiscriminate solid waste disposal on human and its environment in Nigeria: A Review. Global Journal of Research and Review. 2019;6(1):1-4.

4. Bakare W. Solid Waste Management in Nigeria. Bio-Energy Newsletter 2021, 5: 6872. https://www.bioenergyconsult.com/solidwaste-nigeria/

5. Mathema M, Shadung JM, Chris LA. A review of the Working Conditions and Health status of waste pickers at some landfill sites in the City of Tshwane Metropolitan Municipality, South Africa. Pelagia Res. Libr. 2017;8:90-7.

6. Bhugra S., Biswas S. Assessment of health hazardous of waste-pickers using intelligent system. Int. J. Emerging Engineering Research and Technol, 2015, 3(9): 41-44

7. Sarkar P. Solid waste management in Delhia social vulnerability study. In Proceedings of the third international conference on environment and health, Chennai, India 2003 Dec 15 (pp. 15-17).

8. Janis B. Tool kit on Social Assessment and Public Participation in Municipal Solid Waste Management, $2004 \quad$ Retrieved https://documents1.worldbank.org/curated/en 1741051468340748098/text/337810socialass esstoolkit.txt

9. Hoornweg D, Bhada-Tata P. What a waste: a global review of solid waste management. Available from: https://openknowledge.worldbank.org/handle/ 10986/17388

10. Awopetu MS, Awopetu RG, Sample ED, Olufiropo AO, Awokola S, Fullen MA, Booth $\mathrm{CA}$, Hammond FN. Municipal solid waste management and the role of waste-pickers in Nigeria. Int J Educ Res. 2014;2:1-2.

11.de Araújo NC, de Oliveira Sato T. A descriptive study of work ability and health problems among Brazilian recyclable waste pickers. Journal of community health. 2018 Apr;43(2):366-71. https://doi.org/10.1007/s10900-017-0432-6

12. Ojeda-Benitez S, Armijo-de-Vega C, RamírezBarreto ME. Formal and informal recovery of recyclables in Mexicali, Mexico: handling alternatives. Resources, Conservation and Recycling. 2002 Mar 1;34(4):273-88. https://doi.org/10.1016/s0921$\underline{3449(01) 00105-7}$
13.Zia H, Devadas V. Urban solid waste management in Kanpur: Opportunities and perspectives. Habitat international. 2008 Mar 1;32(1):58-73.

https://doi.org/10.1016/j.habitatint.2007.08.00 1

14. Wilson DC, Velis C, Cheeseman C. Role of informal sector recycling in waste management in developing countries. Habitat international. 2006 Dec 1;30(4):797-808. https://doi.org/10.1016/j.habitatint.2005.09.00 $\underline{5}$

15.Magaji JY, Dakyes SP. An assessment of socio-economic impact of waste scavenging as a means of poverty alleviation in Gwagwalada, Abuja. Confluence Journal of Environmental Studies. 2011 Jan 1;11(2011):42-56.

16. Nyathi S, Olowoyo JO, Oludare A. Perception of scavengers and occupational health hazards associated with scavenging from a waste dumpsite in Pretoria, South Africa. Journal of environmental and public health. 2018 Aug 9;2018. https://doi.org/10.1155/2018/9458156

17. Simatele D, Etambakonga CL. Scavenging for solid waste in Kinshasa: a livelihood strategy for the urban poor in the Democratic Republic of Congo. Habitat International. 2015 Oct 1;49:266-74.

https://doi.org/10.1016/j.habitatint.2015.05.02 $\underline{9}$

18. Thirarattanasunthon $\mathrm{P}$, Siriwong $\mathrm{W}$, Robson $M$, Borjan M. Health risk reduction behaviors model for scavengers exposed to solid waste in municipal dumpsites in Nakhon Ratchasima Province, Thailand. Risk management and healthcare policy. 2012;5:97. https://doi.org/10.2147/rmhp.s30707

19. Kumar R, Somrongthong R, Shaikh BT. Effectiveness of intensive healthcare waste management training model among health professionals at teaching hospitals of Pakistan: a quasi-experimental study. BMC health services research. $2015 \mathrm{Dec} ; 15(1): 1-7$. https://doi.org/10.1186/s12913-015-0758-7 